ppi $201502 Z U 4645$

Esta publicación cientifica en formato digital es continuidad de la revista impresa ISSN-Versión Impresa 0798-1406 / ISSN-Versión on line 2542-3185Depósito legal pp

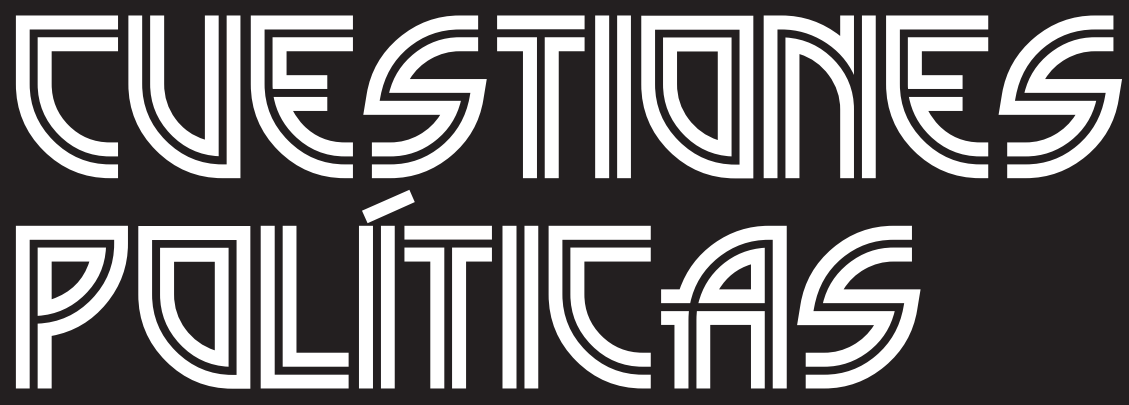

Instituto de Estudios Políticos y Derecho Público "Dr. Humberto J. La Roche' de la Facultad de Ciencias Jurídicas y Políticas de la Universidad del Zulia Maracaibo, Venezuela
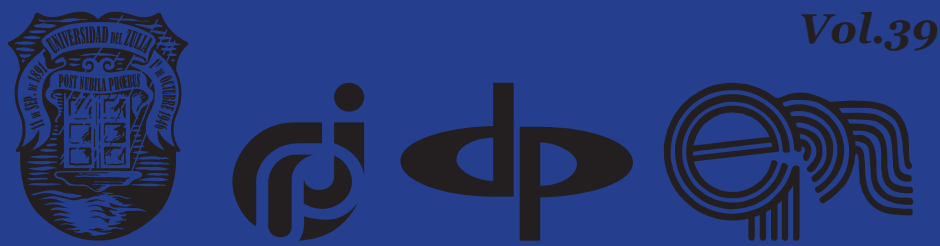


\title{
Evolutionary trends in the interpretation of the European Court of Human Rights under the European Convention on Human Rights
}

\author{
DOI: https://doi.org/10.46398/cuestpol.3968.04
}

\author{
Svitlana Karvatska * \\ Mariia Blikhar ** \\ Nataliia Huralenko ***
}

\section{Abstract}

The purpose of this Article is to analyse evolutionary trends in the interpretation of the European Convention on Human Rights (ECHR) by the European Court of Human Rights (ECtHR). To achieve this goal, a wide range of general philosophical methods were used. The Article submits that the ECHR has shown a growing commitment to the evolutionary method of interpretation, using the doctrine of a «living instrument», the ECHR, which is particularly important for Member States with specific problems, although this method limits the scope in the discretion of the State. It is concluded that the interpretative methodology used by the ECHR involves the use of its methods, including increasingly developing methods of consensus, efficiency, judicial activism, comparison, innovative interpretation, autonomous method, and «balance» method. This demonstrates, inter alia, the unlimited potential to improve the ECHR's interpretation of conventional standards. In the context of modern transformations in the direction of proactive international justice, judicial activism objectively departs from a formal application of legal norms and reflects the ECHR's desire to protect the fundamental human rights of individuals and communicatethem.

Keywords: evolutionary trends in legal interpretation; European Court of Human Rights; interpretation of rules of international law; consensus method; judicial activism.

* Doctor of Science in Law, Associate Professor, Department of European Law and Comparative Law Studies, Chernivtsi National University, Ukraine. ORCID ID: https://orcid.org/oooo-00o1-99484866. Email: svitlana.karvatska288822@gmail.com

** Doctor of Science in Law, Associate Professo, Department of Administrative and Informational Law, Lviv National University Lviv Polytechnic, Ukraine. ORCID ID: https://orcid.org/oooo-00o32974-0419. Email: blikharv@gmail.com

*** Doctor of Science in Law, Associate Professor, Department of Human Rights, Faculty of Law, Chernivtsi National University, Ukraine. ORCID ID: https://orcid.org/oooo-0003-0884-215X. Email: N.huralenko@gmail.com 


\section{Tendencias evolutivas en la interpretación del Tribunal europeo de Derechos Humanos en el marco del Convenio Europeo de Derechos Humanos}

\section{Resumen}

Este artículo tiene como objetivo analizar las tendencias evolutivas en la interpretación del Convenio Europeo de Derechos Humanos (CEDH) por parte del Tribunal Europeo de Derechos Humanos (TEDH). Para lograr este objetivo, se utilizó una amplia gama de métodos filosóficos generales. El artículo sostiene que el $\mathrm{CEDH}$ ha mostrado un creciente compromiso con el método evolutivo de interpretación, utilizando la doctrina de un «instrumento vivo», el CEDH, que es particularmente importante para los Estados miembros que tienen problemas específicos, aunque este método limita el alcance en la discreción del Estado. Se concluye que la metodología interpretativa utilizada por el $\mathrm{CEDH}$ implica el uso de sus métodos, entre los que se están en desarrollo cada vez más los métodos de consenso, eficiencia, activismo judicial, comparación, interpretación innovadora, método autónomo y método de «equilibrio». Lo que demuestra, entre otras cosas, el potencial ilimitado para mejorar la interpretación de las normas convencionales por parte del CEDH. En el contexto de las transformaciones modernas en la dirección de una justicia internacional proactiva, el activismo judicial se aparta objetivamente de una aplicación formal de las normas legales y refleja el deseo del CEDH de proteger los derechos humanos fundamentales de personas y comunidades.

Palabras clave: tendencias evolutivas de interpretación jurídica; Corte Europea de Derechos Humanos; interpretación de normas de derecho internacional; método de consenso; activismo judicial.

\section{Introduction}

Methods of research and analysis have made it possible to determine that the essential feature of the evolutionary approach in modern international legal reality is its focus on humans as the highest value. International human rights treaties are an integral part of modern international law, but they also have their own characteristics. Their distinctive feature is the origin and the nature of the obligations of parties, as human rights treaties are agreements between states that confer specific rights on persons who are not themselves parties to the treaty and for whom their obligations derive from states.

The results of this article made it possible to determine that, on the one hand, the evolutionary approach in international law can contribute to 
its dynamic development; on the other hand, its application can be quite problematic in practice, as there is no exact legal procedure by which to establish its existence. Torp Helmersen (2013) draws attention to the fact that treaties, when concluded, formally remain static; but at the same time the reality in which treaties operate is more complex, it is not static as economic, political, cultural, and technological realities do change. In many areas, the law must be flexible in order to remain relevant and effective; in international law, this flexibility can be provided primarily by the evolutionary interpretation.

This study confirms that, firstly, the evolutionary approach follows from the very meaning of the ECHR as a catalog of human rights, the content of which evolves together with social moral guidelines; secondly, the evolutionary interpretation of law by the ECtHR is closely linked to the teleological interpretation; thirdly, the evolutionary approach involves finding out the consensus of the states parties to the ECHR on the key changes taking place in public life and affecting the content of fundamental human rights; fourthly, the ECtHR recognizes the need for a "cautious" application of the evolutionary interpretation of human rights guaranteed by ECHR, as such an approach could lead to an unjustified extension of obligations of Parties under the ECHR (Kretova, 2015).

\section{Methodology}

Determining a methodological basis was one of the crucial stages of writing this article. The methodology is based on a comprehensive approach to the analysis of object and subject of research, which covers a wide range of general philosophical, general scientific, special scientific and legal methods. A general methodological basis of the study was the dialectical method of scientific knowledge, which provided a comprehensive study of the integral connection of doctrine with practice.

Among the interdisciplinary methods, a special place occupies the system-structural method, on the basis of which system relations in the system of international and national justice were studied and substantiated. The use of the psychological method in this article made it possible to reveal nature and significance of judicial discretion in the administration of international and national justice. The historical method allowed us to trace the evolution of the formation of rules for the interpretation of international treaties. Established patterns, generalisations and conclusions of the author are largely based on the results of scientific analysis of significant law enforcement practice of the ECtHR, carried out by using the empirical method of research.

A critical methodological principle was the logical method of clear construction of the research, which is based on the need to study the 
evolution and development of legal interpretation in international law, emergence, and operation of the ECtHR, which is one of the main subjects of interpretive activity in international law. This logical sequence of examining independent, but inextricably linked issues allowed us to reach a qualitatively new level of reflection of the subject of study and fully solve the tasks set in the article.

Modern methodological approaches such as anthropological and synergetic ones were also actively used in the article. The anthropological method focused on the anthropocentrism of the interpretation process carried out by the ECtHR. The synergetic method allowed to determine basic principles and patterns of functioning of the ECtHR as a subject of interpretation and the formation of its interpretive methodology.

Objectively, the article widely uses legal research methods. In particular, the formal-legal method was used to study treaties and national legislation of Ukraine and to analyse the case-law of the ECtHR and the practice of courts of Ukraine. The comparative legal method made it possible to compare treaties interpretation with other legal interpretations, substantiated the comparative analysis of the peculiarities of European and national justice.

\section{Theoretical framework}

An analysis of the scientific literature certifies that the discussion of approaches is reduced to the analysis of static and dynamic legal interpretative approaches (Bjorge, 2014). For example, according to A. Orakhelashvsvili (2008), the dominance of the evolutionary approach to the interpretation is noticeable in international practice, which is confirmed by the analysis of the ECtHR, which in interpreting the Convention and its Protocols mainly bases its judgement on the spirit rather than on the letter of interpretation.

Professor Ingo Venzke (2015) also speaks about the dynamism of international law in justifying the need for evolutionary interpretation: "The Achilles heel" of international law doctrine is its static understanding of international law so that an act of interpretation looks like restoration, not creation.

Although the evolutionary approach to interpretation has recently attracted the keen attention of researchers, Inagaki Osamu (2015) notes that its application in the judiciary is not fully clarified. The issue is complicated by the fact that one of the main characteristics of the international legal order is the lack of legislative power as such: in this case, it is not entirely clear how treaties can adapt to new situations that arise after their conclusion. One of the possible ways is to change the treaty, but this process is long, so a more flexible option is to interpret international treaties. As argue 
prof. Tymchenko and Kononenko (2012), the evolutionary interpretation provides a gradual development of the content of the international agreement due to changes taking place in society.

In the context of ECHR `s interpretation, it is important to consider certain aspects of such a legal phenomenon as judicial activism. W. Marshall (2002) identifies features of judicial activism. Dothan (2018) explores factors and causes of national systematic bias of judges. Evseev (2015), sharing the position of the retired ECtHR judge A. Kovler, notes that judicial activism occurs when the Court has several interpretations within its case law, but the Court goes beyond that. S. Sherry (2014), emphasizing positive characteristics, underscores that judicial activism in a certain sense of civilization is an attribute of a democratic legal system.

\section{Results and discussion}

\subsection{The object and the purpose of human rights treaties}

In general, the object and the purpose of human rights treaties, is to protect the rights of the individual and to play a central and crucial role in their interpretation. In accordance with this task, the interpretation must be carried out consistently and must adhere to certain established principles, among which, first of all, the principle of efficiency, evolution, autonomy. European Convention on Human Rights (the ECHR - the Convention) of 1950 was the first mandatory instrument to protect human rights, interpretation of which is carried out by the European Court of Human Rights (the Court - the ECtHR) (Wildhaber, 1998).

The evolutionary approach has become especially popular in ECtHR `s pratice. According to Art. 32 of the ECHR, the Court is called upon to decide all issues of interpretation and application of the ECHR and its Protocols in resolving interstate cases, considering individual complaints, issuing advisory opinions. In fact, ECtHR`s judges are empowered to interpret the ECHR and its Protocols, within the framework of the evolutionary approach, taking into account changing life realities. They use this power in practice - the tendency is called "judicial activity" or "judicial activism".

Inagaki Osamu (2015) identifies two stages of judicial interpretation in ECtHR `s case-law. In the first stage, as the author notes, it is established whether the term or the provision can be interpreted in the context of circumstances existing not at the time of their application, but at the time of their adoption. If the result is positive, the interpretation proceeds to the second stage, in which the interpretation will be carried out considering various circumstances that have arisen since the conclusion of the treaty. Inagaki Osamu (2015) considers the ECtHR to be the most "interpretive", 
in other words one that prefers the evolutionary interpretation, more often bearing in mind the circumstances that arise after the conclusion of the treaty, not only further development of international law but also further practice.

The interpretation of the legal provisions of the Convention for the Protection of Human Rights and Fundamental Freedoms by the European Court of Human Rights is characterized by indeterminate dynamics, the presence of socio-cultural determinant spontaneity of the emergence of new social situations (Huralenko et al., 2020).

However, researchers are faced with an important question: is the evolutionary approach in the process of interpreting international law a clear positive trend? It is worth noting that the evolutionary approach cannot completely displace a static approach, as the latter is in a sense a "guarantor" of the rule of law.

Regarding the effectiveness of the mechanism of the Court and the evolution of the organizational structure due to the growing number of cases after the expansion of its jurisdiction to the East, one may primarily pay attention to certain institutional features that affect ECtHR`s interpretational activity.

Initially, the main body to which individuals could file complaints was the European Commission of Human Rights. If the dispute has not been settled, the Commission submitted a report either to the Committee of Ministers, or to the Court. One of these bodies had to consider and solve the case. The case was heard in plenary sessions or chambers (comprising 7 judges). When Protocol No. 11 entered into force, a new single body was set up in place of the Commission and the Court, the European Court of Human Rights, which could deal with complaints on its own and issue decisions in all cases. The admissibility of complaints was determined by committees (comprising 3 judges) and chambers (comprising 7 judges) considering both the admissibility and the cases themselves.

The most important cases concerning theinterpretation of the Convention were to be discussed in the Grand Chamber (comprising 17 judges). The incredible workload of the ECtHR and the length of the proceedings led to the adoption of Protocol № 14, which allowed judges to determine the admissibility of cases individually, and committees (comprising 3 judges) were given additional powers to issue decisions in ordinary cases. It is clear that institutional improvements speed things up but reduce the ECtHR's ability to focus on each case. The Parliamentary Assembly of the Council of Europe elects 14 judges for a term of 9 years from among the candidates nominated by each member state. Each judge may serve in its capacity only for one term. The prerequisite is the compliance of candidates with high moral and ethical qualities. 
Svitlana Karvatska, Mariia Blikhar y Nataliia Huralenko

Evolutionary trends in the interpretation of the European Court of Human Rights under the European Convention on Human Rights

It is also assumed that judges will be politically unmotivated. However, in the literature we find research on the national systematic bias of judges due to certain factors: psychological (patriotic beliefs); economic (expected material reward); selection conditions (adherence to a certain ideology); cultural (education, experience gained in the country) (Dothan, 2018). At the same time, it seems that it would be possible to avoid a biased interpretation due to the careful formation of the composition of judges for consideration of cases. However, scholars observe the formation of coalitions between biased judges through legal reasoning or as a result of leaning in favor of one's own state. "A systemic bias that does not favor a particular state, but rather is a judicial policy" among judges from the former socialist countries, in particular, is stressed as well (Dothan, 2018).

Over the last decade, the ECtHR has formed a research unit that conducts research on issues of comparative and international law, which arise mainly in cases considered by the Grand Chamber. As a result, the ECtHR has at its disposal extremely useful and detailed comparative and international legal information, as well as the collective knowledge of its members, the registers of the Court, and the research of the amicus curiae of non-governmental organizations (Harris and O'Boyle, 2014).

Interpretative rules are an important basis for ensuring the proper exercise of the right to a fair trial at the national level. Interpretative rules applicable to treaties, in general, are also applicable to human rights treaties, as is the undoubted application in such cases of the principles of interpretation provided for by Art. 31, art. 32 and Art. 26 of the ECHR. Namely, principle of good faith (the treaty must be interpreted "in good faith"), principle of literality (the contract must be interpreted in accordance with the usual meaning of the terms of the treaty, in their context), principle of systematic nature systematic view of the whole treaty, teleological principle (according to the subject and the purpose of the treaty).

However, the interpretation of human rights treaties requires a special approach and taking into account the specific characteristics of these treaties. Since the ICJ has established that treaties should be interpreted and applied within the legal system that existed at the time of interpretation, and not at the time of preparation or adoption of the text, there is no point in talking about the need to clarify the intentions of their developers. Sometimes ECtHR's decisions run counter to developers' intentions. Thus, the retired judge of the ECtHR prof. Butkevich (2010) emphasizes:

It is true that the Convention and its Protocols must be interpreted in the light of the conditions which exist today, but the Court can not, just for the purpose of evolutionary interpretation, derive from the Convention a right not originally included therein (2010: 83). 


\subsection{Method of consensus as a manifestation of the evolutionary approach in the activities of the ECtHR}

Jurisdiction of the ECtHR, according to Art. 32 of the ECHR, includes "all matters concerning the interpretation and application of the Convention and of the Protocols". The Court must also give reasons for its decisions (Article $45 \S 1$ ), which are binding only for the State party to the proceedings, as the defendant or the applicant.

The ECtHR has repeatedly emphasized that it adheres to the interpretative principles of the ECHR. In its interpretative practice, the Court uses the Convention in different ways: sometimes in a latent form as a common practice. But the same practice shows that the Court uses its own methodology of interpretation, which is based on the method of consensus, in other words, the combination of interpretation of international treaties (the ECHR) with the practice of Member States (national legal system), use of fairly broad standards, analysis of interpretations of Constitutional Courts of the Member States. The consensus method is certainly a manifestation of the evolutionary approach of the Court, which is particularly important for the Member States with similar problems, although it limits the scope of the State's discretion.

Among the reasons for using the consensus method, the judges of the ECtHR single out the following:

1) strengthening the legitimacy of the ECHR in the case of evolutionary interpretation.

2) the need to persuade the Contracting Parties and issue acceptable court decisions.

3) avoidance of arbitrary decision-making (for example, when judges prefer their own moral views).

4) determining the scope of discretion.

5) assisting the Court in resolving new issues of interpretation (of the Convention), issues of special importance or in dispute(Dzehtsiarou, 2015).

Being convinced that "the Court's flexible and non-automatic approach to the European consensus can provide a sufficient guarantee against the abuse of a majority logic in the case-law of the ECtHR" most ECtHR `s judges supported the possibility of conceptualizing the European consensus "as a rebuttable presumption if there are good reasons" (Dzehtsiarou, 2015: 204). 
Svitlana Karvatska, Mariia Blikhar y Nataliia Huralenko

Another feature of the Court's interpretation of the Convention is the use of a self-developed autonomous method, which is based "primarily on the domestic law of the Member States and their international obligations" but is not limited to the meaning of certain concepts within national legal systems, which can significantly expand their content. At the same time, the Court uses the "balancing" technique, which it applies in the following cases:

1) if the Court has found interference with the law, it determines whether such interference was justified (proportionality of purpose and requirements).

2) when the Court decides whether there is unjustified discrimination in the application of Art. 14 of the Covention together with other articles.

3) if the Court recognizes that certain rights also have a positive dimension in the sense that they not only guarantee the absence of State interference but also oblige the State to actively protect those rights (ECHR, 2002);

4) The Court from time to time determines the meaning of very vague terms through a balancing process (Djeffal, 2016).

\section{3 "Judicial activism" as a peculiarity of the ECtHR`s interpretation}

One of the peculiarities of the dynamics of interpretive activity of the EctHR is its intellectual and creative nature; mechanical transformation of legal rules into individual acts and "standard" use of previous court decisions are not allowed (Huralenko et al., 2020). Another issue is a peculiarity of the interpretation of the EctHR is the tendency to "judicial activism". This term has been used since 1947. Today it is firmly established in the scientific and categorical apparatus of researchers of international and European law, but it is used in different meanings. As a rule, it is used to criticize judges who do not simply interpret or apply the legal text in an active way but decide cases without taking into consideration the rule of law that they intend to apply. Or it is used to accuse judges who do not adhere to the principle of integrity in making decisions.

W. Marshall (2002) identifies the following signs of judicial activism: 1) counter-majority, when courts overturn decisions taken by representative bodies; 2) refusal of courts to comply with the law; 3) refusal of courts to take into account existing precedents; 4) the refusal of courts to comply with the established limits of their jurisdiction; 5) creation of new doctrines 
and rights; 6) use of the judiciary power to establish new responsibilities for other branches of government; 7) the use of the judiciary to promote their own interests.

Judicial activism is understood as cases when international courts go beyond the wording of treaties, which define the scope and intentions of states. The discussion on the judicial activism of international courts mainly focuses on their interpretive and law-making activity, which was not envisaged by states when creating a particular international court. The Court of Justice of the EU, which indicated a qualitatively new procedural way to solve a number of doctrinally confusing and practically unsolvable legal problems, is considered to be the most "activist" (Karvatska, 2019).

The activities of the Court in the context of "judicial activism" are manifested in several forms. For example, sharing the position of A. Kovler (2010), a resigned judge of the ECtHR, Evseev (2015) notes that "judicial activism" occurs, firstly, when the Court has several interpretations within its case law, but the Court goes beyond this framework. Secondly, when the Court searches for certain procedural procedures (the author cites the example of the "Katyn case", Janowiec and others v. Russia (ECHR, 2013), when the Court did not reject the complaint as not meeting the criterion ratione temporis and opened proceedings.

Among the many drawbacks of "judicial activism", the most significant is the reluctance of courts to take into account the will of representative authorities (in cases of ignoring legislation). But, in contrast to the critique of "judicial activism", we agree with the arguments of the American Professor S. Sherry (2014) that the activism is in some civilisational sense a quality of a democratic legal system. As Prof. Savchyn (2016) notes, speaking about peculiarities of the domestic justice system, the judge's discretion is to choose the best solution to a legal case, based on fundamental principles of law, in particular, respect for human rights, the rule of law and democracy. The scholar refers to Lord Bingham's view that in modern requirements of the rule of law, judicial discretion should be exercised cautiously on reasonable grounds, with little freedom of choice, and judges should not be inclined to over-innovate the law, especially when new laws are passed.

The term "judicial activism" is also used to denote limits of treaties interpretation. The requirement not to use undesirable "judicial activity" consists in the fact that the treaty interpreter must respect wording, context and its objective purpose and can not perform law-making functions (create the rule of law). But, at the same time, if the interpreter does not allow himself to carry out "undesirable" judicial activity, then a certain share of activity may not only be permissible, but also, on the contrary, "desirable", for example, in a situation where a certain wording is unclear to the interpreter. It should be noted that "judicial activism" mainly concerns the interpretation of the rules governing disputes. Thus, the main problem 
Svitlana Karvatska, Mariia Blikhar y Nataliia Huralenko 98 Evolutionary trends in the interpretation of the European Court of Human Rights under the
European Convention on Human Rights

relates to a possible undesirable (or intentional) deviation from the true interpretation of legal requirements.

The phenomenon of "judicial activism" in international justice has its own characteristics. Firstly, regardless of whether an interpretation can be regarded as a judicial activity, it is definitely closely linked to the text of the treaty itself. Secondly, when an international judge issues a decision on a case, he must, at his own discretion, interpret the treaty and, at the same time, not deviate from the general principles of treaty interpretation. Thirdly, international judges must have restrictions on the exercise of their powers. Such requirements include a fair interpretation of the text of the applicable international treaty and a reasoned implementation.

However, in the context of understanding the true nature of judicial discretion, treaty interpretation should not be limited to the actual interpretation of the "letter" of the text of the treaty. A judge may (and should) use the opportunity to fill a gap in the regulation of a treaty, if necessary, to ensure its effect. This issue, like no other, requires balance. We share the position of Taiwan University Professor Chang-fa Lo (2017) that it is inappropriate to treat the term (concept) "judicial activism" only negatively, as its non-recognition may lead to a situation where an international judge will not be able to properly interpret the treaty resulting in failure to fill a gap and, ultimately, in non-performance of the treaty.

A disadvantage of the evolutionary approach is seen in the fact that judicial activism can lead to the fact that the contractual rule may eventually be interpreted quite unexpectedly for the state - a party to the treaty (Zaharova, 2016). An example of the evolutionary interpretation is the judgment in the case of Christine Goodwin v. The United Kingdom, (ECHR, 2002). Guided by the principle of subsidiarity, the ECtHR emphasized that States have a wide margin of discretion to decide which measures are necessary to exercise conventional rights within their jurisdiction and to address practical issues related to the legal implementation of the postoperative gender status of such persons.

The Court attached less importance to the lack of evidence of the existence of the single European approach to legal and practical problems than to clear and unequivocal evidence of an international tendency, which favors not only of an increased public acceptance of transgender people but also a legal recognition of their new sex after surgery. In other words, the Court did not burden itself with seeking consensus and issued a decision on the basis of possible changes (Zaharova, 2016). 


\section{Conclusions}

A study and an analysis of evolutionary trends in interpretation are important from the point of view of increasing the efficiency and effectiveness of legal interpretation of the ECtHR and national authorities applying the ECHR, what is extremely important for parties recently acceded to the Convention. In legal systems of such member-states mainly technical-dogmatic methods of interpretation still prevail and judges don ' $t$ have the necessary skills to use international jurisprudence in the national legal system. The application of ECtHR`s decisions in national practice allows solving not only problems of justice, but ones of a political, economic and social settlement.

Peculiarities of the ECtHR's interpretation are the special nature of international human rights treaties and of the ECHR in particular, what determines the actualisation of their interpretation in the context of the object and the purpose of treaties, in other words paying attention to the protection of individual rights, but not to the intentions of the memberstates in concluding the ECHR. There are also peculiarities of interpretation of institutional nature, which created certain differences at different stages of organizational transformation of the ECtHR.

An interpretational methodology developed by the ECtHR involves the use of its own methods, among which the methods of consensus, efficiency, judicial activism, comparison, innovative interpretation, autonomous method, and the method of "balancing" are becoming more and more exploited. The functioning of the ECtHR as a court, its interpretive method of building a holistic system through informal practice and setting standards by comparing the legal rules of member states, seem legitimate enough to define identifying evolutionary standards, and maximally contribute to their establishment and consolidation. The binding nature of ECtHR 's decisions only for parties to the dispute does not preclude, rather even affirms the need for the legislation of the Member States to comply with these standards, which must be sufficiently broad. Otherwise, the Court may be charged with "legislative" decisions. However, too broad standards make it incredibly difficult for the Court to operate.

The ECtHR, in compliance with the standards of interpretation provided for in Art. 31, Art. 32 and Art. 26 of the ECHR, has developed its own system of methods, approaches, principles - the methodology of interpretation, in which most attention is paid to the method of consensus, efficiency, activism.

A consensual examination allows the ECtHR to tie its decisions to the pace of changes in national law, recognising the political sovereignty of the respondent States and, at the same time, legitimising its own decisions against them, adhering to the principles of a democratic state governed by the rule of law. 
Svitlana Karvatska, Mariia Blikhar y Nataliia Huralenko

100

Evolutionary trends in the interpretation of the European Court of Human Rights under the European Convention on Human Rights

The ECtHR demonstrates a growing commitment to the evolutionary method of interpretation, applying the doctrine of the "living instrument", but always relies on a thorough study of the domestic law of the Member States, their international obligations and law enforcement practices. A method of the consensus, which the ECtHR mostly uses for interpretation, does not fit into the provisions of paragraph 3 of Art. 310f VCLT rules. Discussions and court decisions often involve a focused approach, primarily to object and purpose, context, and subsequent practice of increasing human rights standards. At times this fact accelerates positive changes in national legislation and sometimes states a regression in domestic law. Regarding the problem of "judicial activism" in ECtHR`s justice, we summarise that, despite heated discussions on this issue, positive "activist" characteristics in its practice include the expansion of judicial competence and new approaches to treaty interpretation. In the context of profound modern transformations in the direction of objective international justice, judicial activism as a way to realise the fair nature of law reflects the trend according to which the Court seeks to increase its activity in protection of fundamental rights and objectively departs from the formal application of legal rules. Examples of ECtHR `s judicial activism encourages to seek to identify within ECHR new potential human rights opportunities.

\section{Bibliographic References}

BJORGE, Eirik. 2014. The Evolutionary Interpretation of Treaties. University Press. Oxford, United Kingdom.

BUTKEVICH, Volodymyr Grygorovych. 2010. European Convention on Human Rights: Genesis of intentions and law. Law of Ukraine. No. 10, pp. 82-83.

CHANG-FA, Lo. 2017. Treaty interpretation under the Vienna Convention on the Law of Treaties. Springer Nature Singapore Pie Ltd. Gateway East, Singapore.

DJEFFAL, Christian. 2016. Static and evolutive treaty interpretation: A Functional reconsruction. Cambridge University Press. Cambridge, United Kingdom.

DOTHAN, Shai. 2018. "The Motivations of Individual Judges and How They Act as a Group” In: German Law Journal. Vol. 19, No. 7, pp. 2165-2188.

DZEHTSIAROU, Kanstantsin. 2015. European Consensus and the Legitimacy of the European Court of Human Rights. Cambridge University Press. Cambridge, United Kingdom. 
ECHR. 2002. Case of Christine Goodwin v. the United Kingdom. Application no. 28957/95. Available online. In: https://hudoc.echr.coe.int/app/ conversion/pdf/?library $=$ ECHR\&id $=002-5265 \&$ filename $=002-5265$. pdf\&TID=ihgdqbxnfi. Consultation date: 14/12/2019.

ECHR. 2013. Case of Janowiec and Others v. Russia. Applicatiom no. 55508/o7 and 29750/o9. Available online. In: http://hudoc.echr.coe.int/eng\#\{«it emid»[«001-127684(2)»]\}. Consultation date: 14/12/2019.

EUROPEAN CONVENTION ON HUMAN RIGHTS. 1950. (as amended by Protocols Nos. 11 and 14, supplemented by Protocols Nos. 1, 4, 6, 7, 12 and 13). Available online. In: https://www.echr.coe.int/Documents/ Convention_ENG.pdf. Consultation date: 14/12/2019.

EVSEEV, Alexander Petrovich. 2015. How the European Court "judges" history (on the issue of judicial activism). Problems of legality: Collection of Scientific Works. Mudryi National Law University. Kharkiv, Yaroslav.

HARRIS, David John; O'BOYLE, Michael. 2014. Law of the European Convention on Human Rights / Ed. E. P. Bates, C. M. Buckley. 3nd ed. Oxford University Press. Oxford. United Kingdom. Available online. In: https://books.google.com.ua/books?id=NvH8AwAAQBAJ\&printsec=fr ontcover\&hl=ru\#v=onepage\&q\&f=false. Consultation date: 14/12/2019.

HURALENKO, Nataliia; VOLOSHCHUK, Oksana; SLYVKA, Stepan. 2020. "Interpretive activity in thejudge's professional occupation" In: Amazonia Investiga. Vol. 9, No. 29, pp. 427-431. https://doi.org/10.34069/ AI/2020.29.05.47. Consultation date: 14/02/2020.

INAGAKI, Osamu. 2015. "Evolutionary Interpretation of Treaties Re-examined: The Two-Stage Reasoning" In: Journal of International Cooperation Studies. Vol. 22, No. 2/3, pp. 127-128.

KARVATSKA, Svitana Bohdanivna. 2019. Dillemma of juridical activism in international justice. Scientific notes of Tavrida National V.I. Vernadsky University. Series "Legal studies". Tom 30 (69) num 1. Pp. 134-138.

KOVLER, Anatoly. 2010. "Scylla and Charybdis of the European Court: Subsidiarity or Legal Activism?” In: Comparative Constitutional Review. Vol. 6, No. 79, pp. 90-100.

KRETOVA, Iryna Yuriivna. 2015. Interpretation of law: doctrines developed by the European Court of Human Rights. (Ph.D. Thesis): 12.00.01. Kharkiv, Ukraine.

MARSHALL, William P. 2002. "Conservatives and the Seven Sings of Juidcal Activizm” In: University of Colorado Law Review. Vol. 73, No. 4, pp. 1217-1255. 
Svitlana Karvatska, Mariia Blikhar y Nataliia Huralenko

ORAKHELASHVSVILI, Alexander. 2008. The Interpretation of Acts and Rules in Public International Law. Chap. 10. Oxford Unisversity Press. Oxford, United Kingdom.

SAVCHYN, Mykhailo. 2016. Freedom of judicial discretion in the light of the validity of decisions of courts of appeal and courts of cassation. Legal Bulletin of Ukraine. Available online. In: https://yvu.com.ua/ svoboda-suddivskogo-rozsudu-u-svitli-obgruntovanosti-rishen-sudivapelyatsijnoyi-ta-kasatsijnoyi-instantsij/ Consultation date: 14/12/2019.

SHERRY, Suzanna. 2014. Why We Need More Juridical Activizm. Constitutionalism, Executive Power, and Popular Enlightenment: Vanderbilt Public Law Research Paper Num 13-3. Available online. In: https://papers.ssrn.com/sol3/papers.cfm?abstract_id=2213372. Consultation date: 14/02/2020.

TORP, Helmersen S. 2013. "Evolutive Treaty Interpretation: Legality, Semantics and Distinctions" In: European Journal of Legal Studies. Vol. 6 No. 1, pp. 129-130.

TYMCHENKO, Leonid Dmytrovych; KONONENKO, Valerii Petrovych. 2012. International law: a handbook. Znanja. Knowledge. Avaliable online. In: http://westudents.com.ua/glavy/64772-69-tlumachennyamjnarodnih- dogovorv.html. Consultation date: 18/06/2019.

VENZKE, Ingo. 2015. "Semantic Authority, Legal Change and the Dynamics of International Law" In: No Foundations: An Interdisciplinary Journal of Law and Justice. Vol. 12, p. 1.

WILDHABER, Luzius. 1998. The place of the European Court of Human Rights in the European Constitutional landscape: Address. Conference of European Constitutional Courts XIIth Congress / Council of Europe. European Court of Human Rights. Available online. In: http:// www.confeuconstco.org/reports/rep-xii/Report\%20ECHR-EN.pdf. Consultation date: 14/02/2020.

ZAHAROVA, Larisa Ivanovna. 2016. The evolutionary approach in international law as a new trend in treaties interpretation. The future of international law: collection of articles. LLC "Prospect”. Moscow, Russia. 
ISSN 0798-1406 Depósito legal pp 198502ZU132

\section{Cuestiones Políticas}

\section{Planilla de suscripción}

Nombre

Institución

Dirección

Ciudad País

Cheque de gerencia a nombre de: Universidad del Zulia (LUZ),

Facultad de Ciencias Jurídicas y Políticas, Ingresos Propios

Banco Occidental de Descuento, Cuenta corriente № 212700890-9

Tarifa de suscripción por un año (dos números):

Venezuela: Bs. 80 + Envío

Ejemplar solo: Bs. $40+$ Envío

América Latina \$ $40+$ Envío

Resto del mundo $\$ 50+$ Envío

Esta planilla debe ser enviada a la siguiente dirección:

Revista "Cuestiones Políticas"

Facultad de Ciencias Jurídicas y Políticas

Instituto de Estudios Políticos y Derecho Público

Apartado Postal 526, Maracaibo Venezuela

Puede adelantar información por: cuestionespoliticas@gmail.com

loichirinosportillo@gmail.com 